\title{
Learning to rebel
}

\author{
Elsie Luna and Andrew Mearman* (i)
}

\begin{abstract}
Background: As a response to collective failure to move adequately towards sustainability, youth movements have grown. This article explores the experiences of one young climate activist, Elsie Luna. The article is the product of conversations between the co-authors, augmented by written material by Elsie Luna. The article seeks to avoid adultism, that is, the power that adults have over children; hence it is written principally using Elsie's own words, with minimal translation or interpretation. The article reflects on three key recent events in Elsie Luna's activism: her approach to the London headquarters of several oil companies; her 'dying' symbolically at the BBC in Berlin; and her recent involvement in the large Extinction Rebellion actions in London.

Findings: The article suggests that these events offer insights on learning. Specifically, she is formulating views on sustainability, on system change and associated strategies, and developing a moral position on these matters. She has learned socially, from family and other immediate influences, and from activism. Thus, further, she has learned from experience, but has done so in her own self-managed way.
\end{abstract}

Keywords: Experiential learning, Social learning, Adultism, Extinction Rebellion

\section{Introduction}

Arguably, the prospects for sustainability look bleak [1]. Planetary boundaries have been breached in terms of resource use and species extinction. The prevalence of carbon dioxide-equivalent particles in the atmosphere has increased to what may already be catastrophic levels. Concurrently, climate change denialism has created the impression of disagreement on climate science, helping to block essential action. Reflecting this negative picture, dissatisfaction of environmentalists appears to have grown. One recent manifestation of discontent is the emergence of Extinction Rebellion, a global organisation utilising direct action such as disruption of transport routes in major cities.

A prominent feature of this new activism has been the emergence of youth movements. One significant development has been inspired by Greta Thunberg, a Swedish schoolgirl. She argued that school was not equipping her for the climate crisis. Moreover, she claimed that children, those most likely to be affected by climate change, should be heard. Further, children needed to act because

\footnotetext{
* Correspondence: a.jmearman@leeds.ac.uk

Economics Division, Leeds University Business School, Leeds LS2 9JT, UK
}

adults were failing to do so. All of these reasons led to her go on a climate school strike. Thunberg's actions have inspired a series of school strikes, involving an estimated 1.4 million worldwide refusing to attend school on 15th March, 2019 [2].

This article focuses on one young climate activist, Elsie Luna (hereafter EL). At the time of writing EL was 11 years old, but her actions had already led to her being profiled in The Times [3] and online [4], invited to speak at protest events organised by Extinction Rebellion, and nominated for a Green Heart Hero award for Individual Inspiration by the Climate Change Coalition, a group of 130 English associations. The purpose of the article is to present her reflections on her climate-related actions, and to draw out what these mean for her implicit mode of learning, her understanding of political process, and her moral and ethical positions.

The article is the product of conversations between the co-authors, augmented by written material by EL. The article is written principally using EL's own words, with minimal translation or interpretation: therefore, it seeks to avoid adultism, that is, the power that adults have over children [5]. The conversations draw on Dewey's concept of experience (Dewey, $[6,7]$ ), that is, as

(c) The Author(s). 2020 Open Access This article is licensed under a Creative Commons Attribution 4.0 International License, which permits use, sharing, adaptation, distribution and reproduction in any medium or format, as long as you give appropriate credit to the original author(s) and the source, provide a link to the Creative Commons licence, and indicate if changes were made. The images or other third party material in this article are included in the article's Creative Commons licence, unless indicated otherwise in a credit line to the material. If material is not included in the article's Creative Commons licence and your intended use is not permitted by statutory regulation or exceeds the permitted use, you will need to obtain permission directly from the copyright holder. To view a copy of this licence, visit http://creativecommons.org/licenses/by/4.0/. 
a combination of the process of experiencing and its results. This notion of experience, which has both subjective and objective dimensions, is future looking, and has ethical, aesthetic and emotive elements (see [8]). The article considers three key recent events in EL's activism: her approach to the London headquarters of several oil companies; her 'dying' symbolically at the BBC in Berlin; and her recent involvement in the large Extinction Rebellion actions in London. These events suggest a theory of systemic change, which EL outlines. The article also seeks to trace roots of EL's understanding and activism.

The article begins by discussing some key methodological features, illustrating its rather unusual nature. Second, three acts of rebellion by EL are retold in her own words. Third, we present some of EL's thoughts on how she became a rebel. Fourth, from later conversations with her, she outlines why she has changed her mind on some key points. Finally, we offer some reflections on what EL's account tells us about her learning to rebel.

\section{Ethical and methodological issues}

This article is unusual, most strikingly because one of its authors is 11 years old. That fact alone generated ethical and methodological challenges that the authors and the guest editors worked to overcome. These features require elucidation.

Initially, the lead guest editor of this special issue approached Elsie Luna, via her mother, to ask if she would consider writing an article about her experiences. The lead guest editor suggested that EL work with an academic who could facilitate bringing the article to fruition, leading EL's mother to approach Andrew Mearman (hereafter AM), EL's godfather. AM and the lead guest editor then discussed a possible form for the article, which needed to do three things: represent EL's experiences; meet the objectives of the special issue; obey typical academic convention. Subsequently, EL and AM held a series of conversations, the product of which was an abstract and draft that the guest editors reviewed. That led to another conversation between the authors, which proved significant (see $A$ change of mind). Aside from the slightly untypical step of guest editors reviewing drafts before sending out for full review, this process throws up ethical and methodological issues.

Had the article been typical, that is, a researcher observes or interviews an 11-year-old subject, the following ethical issues would arise. First, the subject is a child and regarded as vulnerable and perhaps unaware of the context, and therefore unable to consent informedly. Thus, a parent (or other supervisory figure) must explain the research to the child to gain their consent. Even then, the researcher must check themselves if the subject wants to proceed. Still, assent is necessary: the researcher must check periodically with their subject that they are happy to continue. This checking can be done formally by asking the person; and by being sensitive to their mood. Like all research subjects, the child can withdraw from the study (including, where possible, their data). Further, interviews or observations must be carried out appropriately. For instance, the researcher must interrogate their own research questions for potential harm to their subject. Even then, the researcher must establish procedures for addressing any distress the subject might experience. Once the interview or observation has happened, the researcher must comply with protocols on reporting and any agreements made with the subject's guardian. For instance, they must agree that the subject and their parent are content that their words are used as the researcher intends.

The case related in the present article is similar to this standard story, but also different. The first similarity regards consent. When the article was first mooted, AM and EL, also mediated by EL's mother, established EL's willingness to participate. Before their conversations, AM checked that EL wanted to work on the article and that she understood the writing process. These steps are necessary in case EL felt coerced by her mother. Obviously, given the nature of the goddaughter-godfather relationship, EL may have felt obliged to write the article once AM had committed to it. To ensure against this, AM checked with both of EL's parents that she was content with the process. Moreover, AM continually checked for EL's assent throughout the writing of the article. These steps reduce the risk that EL was not fully assenting. Similarly, usual protocols were followed in terms of conducting conversations with EL transparently, either via recordings of face-to-face discussions, or via electronic media, fully viewable and reviewed by EL's mother. Thus, potential channels for causing harm to the vulnerable participant were closed off and/or monitored.

This case does suggest a potential source of harm that is unusual. Specifically, in writing the article and in discussing EL's views it was important not to impose a narrative on her. This type of concern reflects feminist methodology [9] and emancipation paradigms [10], which have addressed the challenge of capturing and reporting under-privileged, vulnerable or 'different' voices. In this instance, the vulnerability for EL concerns her age. AM needed to avoid 'adultism', that is, the expression of the power that adults have over children, particularly in making assumptions about their ability to process information, form opinions, or convey their views [11].

Clearly, adultism has its limits. Educational developmental psychology literature suggests that children have limitations relative to adults, for example in their capacities to reflect critically. Thus, although EL can relate her 
activities, she may not be capable of reflecting in depth on why she did them. Yet, this does not mean that children are incapable of critical self-reflection. Thus, the child should be invited to engage in it. So, a typical investigation involving a child as a subject requires that the researcher and child develop the account of the child's thinking dialectically. Doing so allows the adult researcher to avoid adultism whilst recognising that developmentally, the child may not yet have certain capacities.

Adultism is relevant here for two reasons. First, in developing the article, the guest editors of the journal and the adult author (AM) faced a tension between its original intention - providing a vehicle for EL to express herself - and conventional academic requirements to provide analysis, interpretation and commentary. Second, as will become clear, EL consciously rejects adultism. Hence, the challenge for AM was to convey EL's words in a conventional academic style; offer enough analysis to satisfy other conventions as well as the demands of guest editors, acting as representatives of the academic community; whilst avoiding adultism.

Thus far in this section, some typical ethical and methodological issues of working with children have been discussed. However, this study differs from the typical case in two key ways. First, here, the child is a co-author, not a subject. Second, the child is not being interviewed but instead involved in a conversation, an exchange of ideas, focused on the child expressing their views that are interrogated with them.

Now, taken at face value, these points would seem to neutralise many of the issues above; however, they do not. As Gallacher and Gallagher ([12], p. 499) note, participatory research with children "may involve children in processes that aim to regulate them". Whilst EL is a co-author, it would not be credible to claim that she is an equal coauthor. The two authors are in a multi-dimensional relationship involving several asymmetric power relations: child-adult, lay person-academic, goddaughter-godfather. Further, the adult academic is given power by the journal guest editors to introduce elements of the article that the child may not understand, including analysis of their own actions. It then falls on the adult author to communicate clearly with the child about what is being said, help them understand it and allow them to make appropriate changes. Indeed, it is their duty of care to do so. Thus, it was important to state that at all stages, EL was informed of discussions with the guest editors and consulted about how to proceed.

\section{Three acts of Rebellion}

The remainder of the article focuses on three acts of rebellion undertaken by EL, plus a discussion of how she developed. The sections are a mixture of first-person narrative by EL and extra commentary written by AM and edited by EL. The first-person narrative is shown in italics.

\section{Asking oil companies for a change of heart}

I am 11 years old. I care about my future and about the future of everything on earth. I care about climate breakdown because I do not want people to die. I do not want to have a future where the planet I am living on has seas, acidic and rising, and an atmosphere full of pollution. I don't want to see all these species go extinct. I do not want all the other disasters which will happen because of climate change - flooding, droughts and wildfires, a rising sea level, the food chain will break. It's already happening. And I am determined not to let it get worse.

My mother showed me an article about the $100 \mathrm{com}-$ panies most responsible for global carbon emissions. We came up with the idea to try to talk to them. I found out that many have offices in London. I decided to go find the leaders of the companies. Why are they allowing these emissions to happen when we know what will happen to life on the planet?

I took a sign with a photo of the leader on it, saying "Have a Change of Heart." I told them what percentage of emissions their company is responsible for. Then I asked them, on behalf of the children of the world, to please, please, have a change of heart, declare a climate emergency, and keep their fossil fuels in the ground. People keep telling me and my mother how brave I must have been. But being brave means you are scared. I'm not scared. It's not scary to go up to a receptionist or security guard and ask to speak to someone. It's not the people in the company that I am scared of, it is the effects that the company makes that I am scared of.

If I was an adult, it probably would not work: I would just be a random person, "just another activist". But my being a young person makes a difference, it is then my future that I am talking about, and I am standing right in front of them. It is harder for them. And rather surprisingly, I did get to speak to the Shell country chairwoman, after waiting outside to be let in for nearly $2 \mathrm{~h}$. The next day we did the same thing at BP. Again, I got to talk to someone. This was a big deal. And it got into The Times newspaper, which was also a big deal, as many actions were not getting reported on.

I feel like I got greenwashed by the people I spoke to. They told me that they [the companies] are on track, and that we do not have to go fossil fuel-free to save life on earth. Really, they are telling me they prefer having a comfortable, wealthy life instead of the future of all life. I think of the future; they cannot say they did not know. Shell knew. In fact, everyone knew. Anyway, nothing really changed. We both had a different view on things, yet I did not really get anything to change, but it was still meaningful and it got some publicity. 


\section{'Dying' at the BBC (and elsewhere)}

Climate breakdown has already started. People are already dying. There are climate change refugees already. There are already people fleeing from their home, be it engulfed in flames, drowned in floods, or mined for oil. It has already started. People are dying. Now. Today. Species have already gone extinct. (Every 8 min another one dies out.) And it is not just the woolly mammoths and stuff. It is real animals that many of us will have seen before. It was not that bad for the dinosaurs because it was not their fault that a gigantic asteroid came and killed them all.

That is not like climate breakdown, though, because, in this case, we are doing it. There will be flooding and there will just be so much plastic in the sea and everything will be very polluted and eventually it will just affect us completely even if it is on the other side of the world. Take our food industry: we import so much right now that if somewhere in the world there was a crop failure, it would affect us as well as them. And we will get unexpected weather. It could suddenly become cold, it is possible. Because it is climate chaos, too, not just climate breakdown. That means there is a big threat for our own survival. Humans have a 5\% chance of extinction - a normal adult would not put their children on a plane with a 5\% chance of falling, so why would they put their children, and indeed everything, everything, in that situation with the planet? I am scared for my future.

It makes me sad to know that these species are going extinct. At some events I have been to, people are mourning these extinctions. They hold signs showing the name of a species which has gone extinct. So, 1 day when Extinction Rebellion was holding a protest at the BBC in London, because we were living in Germany, we went to the $B B C$ office in Berlin. It was just a tiny office in the middle of nowhere, which was shut. There were only a few people there and I was the only young person. I did a speech to the BBC about extinction. Then I 'died' twice. I lay on the ground pretending to be dead. This was to symbolise that one species goes extinct every 8 min. Extinction is sad and I want it to stop and I am doing my best to do that. We need to care for the remaining animals, yet we also need to make it so that they no longer need care, so they can live freely in their natural habitat. Yes, there are two big jobs to do. I have done 'dying' in lots of other places. Sometimes, big groups of people are all lying on the floor.

\section{Acts with Extinction Rebellion (XR)}

Extinction Rebellion (XR) is an organisation all over the world. In the UK, they have three basic demands for government: to declare a climate and ecological emergency; to commit to net zero carbon emissions by 2025; and to hold a citizens' assembly to decide on what steps to take. These demands are supported by ten principles, including non-violence, getting outside your comfort zone, and the use of words and actions (see [13]). In many cases, this means civil disobedience, meaning many people get arrested for non-violent action, like roadblocks for example blocking bridges. This is to put pressure on governments to act. As well as these arrestable people, XR has people working in social media. They have others looking after the well-being of those taking action, making sure they are OK, mentally and physically. Then there are people training those people. There are many different jobs. There are also many different groups, both independent and not, such as XR Kids and XR Youth. They all do their own thing, in line with XR's main goals.

One action I was involved in was at the Natural History Museum. This action was by a combination of different groups, including Culture Declares Emergency, who are a group of artists and organisations concerned about the climate. We wanted the museum to declare a climate emergency. We also asked them not to host a dinner paid for by fossil fuel companies. Finally, we asked for the main hall to be renamed - it is currently named after Michael Hintze, who is a[n alleged] climate change denier. I was invited, one of four, to present these demands, in a meeting with the leader of the museum and a couple others from the museum. At first, when I presented the demand about the hall, they claimed that he might not be a climate denier, but then I showed him the facts about how Hintze had donated large amounts of money to one of the first climate denial think tank organizations. At the end, we did not get what we wanted. I was disappointed but not surprised. We could have put more effort in, but really we should not. What we really ought to do is put everything into pressuring the government to get them on our side, and they could get museums to rename their halls. It is hard, because people get burnt out and then less organised. We had a good meeting with the museum, though. It was great to be involved, and afterwards, that was not the end... XR Families had threatened to have a picnic outside the museum, which is the reason why we got the meeting with them, and they did have the picnic! I did the opening speech, meanwhile XR Youth were inside in Hintze Hall, refusing to leave! Then the Samba drummers came, and there was swarming (blocking the road for $7 \mathrm{~min}$, and then 3 min off). Overall, it was really fun!

Actions are fun but there is also a more serious side to them. They are meaningful. They definitely feel like the right thing to do. I do not find them stressful but others sometimes do. On behalf of XR Kids, I am part of a team that helps people not get stressed out, and give them support. It is called the Don't Panic team! I enjoy actions: it is nice working in a community of like-minded people, such as Christian Climate Action, and Grandparents for a Safer Earth. We all support each other. 
These actions get a lot of publicity. They are publicity stunts: that is the point of them. But we only have one planet and if we do not do something soon, it will become uninhabitable. So we have to do something now, no matter how old we are. Just now! I am friends with an 83year-old man who was arrested many times, and I am on the other side of the age scale. So it does not matter how old you are! If you were, like, 100 years old, and you knew you were going to die soon, it is still good to do these actions because, even if it is not for you, it is going to be for your grandkids, for the people you know and for your children and everything. It is still worth it. Every age, no matter how old you are, you should take action.

I will not let climate breakdown happen. People say I should not be doing this. Really, I kind of agree, it is not my fault, and the adults should really be taking responsibility. But they are not, so why not protect the planet if no one else is?

\section{The need for systemic change}

The climate crisis is urgent. What people do now defines completely my life. It is really meaningful. Everyone needs to act now - we have only 11 years left if we want to make a difference. Some scientists even say less than 11. For someone very capable of doing it, there is no arguable reason not to act. There are a lot of little things people can do. People can do things in their free time. Do I blame people if they do not act? No. But how I do react depends on why they do not act. Some people cannot get arrested because maybe they are ill or have child caring responsibilities. But if people do not act because of their jobs, I ask them: what is the point of working? People have been doing it ever since the climate crisis was first discovered, and working has not made it any better! You can leave your job to inspire others: strike! Teachers can inspire their students by taking action for them. Even if you worked for a company which is not taking action, you can be the one that does. If Greta did not strike, a lot would not have happened.

I think people will not act because they are scared to stand up. Especially women and people with less structural power are under-represented. People feel vulnerable and make themselves more so by being scared. We need to fight back against power and privilege. These play very important roles. One way to do this is through citizens' assemblies. These would involve all kinds of people and give power to them. When people are given responsibility, they will take it, use it, not waste it, you will act responsibly. The citizens' assembly will decide what we do as a society. In citizens' assemblies, people will be brave. It will be better than parliament because its members will not be scared about representing the public - they would be the public. That will give a voice to lots of groups who have been silenced. That way, we will get rid of racism, sexism, and adultism, and ageism, which silence different people. We have to do these things if we are going to deal with the really big problem: the climate emergency. And that emergency is something we must face now. That is why I say we focus on that and not on racism and sexism: they have no time limit. It is not that I do not care about them: I care about them very much.

I think this is what is needed to change the system. And that is what we need to do. Small personal sacrifices are not going to save us - people 'recycling bags to save the environment' - this will not work, especially when only $10 \%$ of what we put in the recycling bin actually gets recycled, which brings us to the wider systematic problems again. Stopping flying will not make much difference unless everyone does it, and that is rather unlikely to get it done in time, at this rate. Swapping a car for an electric car might help a bit but we need everyone to do it, or maybe just get rid of cars. It is all very good, individuals becoming vegan, but it is not well promoted and there are not good options for being vegan, it is too expensive. It is hard to eat out if travelling. It is hard to be vegan in this world. The system is wrong. There should not be a choice: everyone should be vegan. People just need to be presented with good vegan options and they would do it anyway. Eating meat should not be an option. It should not be an option to burn our lungs for our own greedy meat consumption... and it shouldn't be up to an 11year-old girl to stop it, when she was just born to a broken system and it was not her fault.

As things are, the world must take responsibility for the climate emergency. We do need to put pressure on big companies; but if governments are not acting, why would any one company do anything because it will not have any effect, a bit like one person's choice to be vegan, currently it is hard. So, we have to put pressure on governments as they are the ones who can change things, for major systematic change. In Cuba, when they left the Soviet Union and had no oil, they had to change their agriculture (around permaculture principles; see [14]). But our governments are making bad decisions. The UK Government trying to expand Heathrow - why are they doing this when they know the facts - and they clearly know the facts. It is just the fault of all the governments who have known about it. Take Bristol, they have declared a climate emergency, yet are expanding the airport. No excuses.

I want to go into politics or journalism to change the course of things. Meanwhile, politicians need to work with the media to make the climate emergency public and, of course, do something: get rid of fossil fuels and much more. We have the answers to all these things, politicians just do not act. They just love their lives, this life that actually pollutes so much. But they do not mind. But I mind and I am not alone. And we will stop this. 


\section{Becoming a rebel}

I have cared about the issues of climate change ever since I could speak. I mean, I was aware of these issues, they were always around. My parents did not hide things from me - they were not adultist towards me. When I was a baby, my mother set up a club at home for people who wanted to change their lives to fight against climate change. They had get-togethers to chat. Ten years later, my mom met them again, as they face court for gluing themselves on to a DLR train [in April 2019] [15]. Much later, I remember hearing a discussion between two neighbours in the time before the 2016 EU Referendum. One was a Remain voter and the other was a Leave voter. I found it really interesting. It made me want to learn more about politics. It seemed to be a big and important issue, the way they were talking about it, something that will affect me, my future. When I am older, I would like to go into politics, but why wait? Young people cannot vote but they care about the same issues as anyone else. So, with a couple of friends, I started a politics podcast called 'Hear, Hear!'. We made podcasts on lots of things, including what politics is, what Brexit is; and I interviewed our local MP, Nic Dakin, and Lord Kerslake, a member of the House Of Lords. Once, we visited a local political party social event and interviewed some of the women about why they like politics.

My parents have supported me in what I want to do and learn. Partly they've done this by home educating me. They believe in unschooling (see $[16,17])$ : if I became interested in something, I was allowed to pursue it. I wrote some books, I learned chess, I grew plants in our garden. I learned about the ecological emergency. When I was at school in Germany, ecology never appeared in class once.

The situation is crazy. I can see the effects of climate emergency already from the experiences of my own family in Florida, Arizona, and Colombia. Florida is hit by a lot of hurricanes. Two years ago, a hurricane was heading for Florida. My family had to hide in their bathrooms. It was really traumatic for them. My family who live in Arizona are experiencing very hot weather; it could become uninhabitable there. Family in Colombia will also be affected by heavy rain which will cause flooding and other extreme weathers. But my information is not just based on personal stories - I have seen the science. I have seen what the science is telling us.

I am a baptised Catholic. My beliefs influence me. I believe God created the Earth and it is our job to protect it. So, acting is the right thing to do. I like working with groups like Christian Climate Action. But I don't put much effort into using religious methods or arguments because some people don't accept them. It is better to stick to the science.

I first heard about a then-15-year old Swedish girl, Greta Thunberg, in October 2018. I already knew about (what I called then) climate change and I realised it is much bigger than I expected. I admire Greta because she is the first one to stand up. She was brave. She went through a lot, had been through depression, but still stood up. Everyone looked up to Greta. If she can do it, I can be powerful, too! She is a role model. All youth activists are role models for each other. People need someone to look up to. This will stop them being silenced and scared.

I am the first person to strike in the UK. I was not actually striking as I was home educated in the UK; but I started to stand outside my local government places in unity with Greta. What I learned from Greta is that children need to act. We the children have to act because adults will not do anything. Well, most of the adults. The man who is 83 years old stands up. I have known him for a while. This man was part of that group my mother set up when I was young. He supported me when I did my protest at the oil companies. And I support him. I went to court with him after he was glued onto a train in London. I look up to him. He is getting arrested and protesting for you, for everyone, for his grandkids, for future generations. He is doing it for me.

\section{A change of mind}

During a conversation between EL and AM in September 2019, EL had made some comments critical of XR, for example regarding the action of using drones against Heathrow airport (see [18]). Further, AM noted the wider criticisms made of XR that it was overtly middle-class and white, and that it was using this privilege, whilst ignoring those less so. For example, by encouraging people to be arrested, it was assuming that arrestees would be treated well: this might not be true for non-white and/or working-class arrestees [19, 20]. Significantly, also, internal criticism of XR had grown (see [21]), particularly about one of its leaders, Roger Hallam, especially after controversial comments Hallam made about the Holocaust [22]. Finally, AM noted that EL's mother's social media posts had become very critical of XR.

For these reasons, AM wanted to explore EL's views again. The subsequent conversation in November 2019 showed that EL had changed her mind on a number of issues. Indeed, amongst these was her sense of allegiance to XR. From being highly committed to XR, and imploring others to join, she now expressed considerable doubts about it, on several levels.

$X R$ is changing: I am not really sure what it is now. I am unsure about its future. XR is like a speeding train, going blindly forward in the wrong direction: should we try to turn the train round or should we try to get off the train? I have written a document for XR Kids [a body independent of $\mathrm{XR}$ ] saying what I should like us to do. If $X R$ Kids do not agree then I will leave and start up another thing. 
I used to think XR was cool and their strategy great, but now I have changed my mind. XR has raised awareness a lot. But the Heathrow action [targeting it with drones] was a fail. People gluing themselves to trains did not work: in effect it stopped the rebellion. What good does it do? What did my actions before actually change? What did dying in Berlin actually change?

$X R$ 's strategy of blocking roads cannot work. XR bases its strategy on past movements such as that led by Gandhi or the civil rights movement, but those movements were very much different because that was absolute direct action. The kinds of action they took was to literally do what they want, for instance walk into the whites only entrance. But we are only talking about blocking roads. Blocking roads cannot bring system change. It is not real direct action. It is not going to work because we are not actively doing what we want to change. So we have got a completely different strategy from what we say we have.

Another reason [that the strategy is flawed] is white supremacy. We are white and mainly middle class. We have completely ignored movements of others who have been fighting much longer. For example, movements for homeless people are fighting starvation right now. We are absolutely fine in our privileged lives. We are saying 'hey, the future's going to be terrible' and here we are in the middle of the road, not doing direct action. We are not doing anything about that. We're not campaigning against homelessness. We are just campaigning against climate change; but if we are just doing that, why not campaign against homelessness? That would be just like campaigning against climate change effects in the present.

[The focus on net zero emissions is also flawed]. Net zero is not enough. The problem with net zero is that we are still releasing carbon emissions. That means that when you are walking by a place where emissions are still being generated, you can still get all the problems that come from emissions, for example lung problems. Also, the green new deal (a plan to transform the economy towards sustainability whilst also creating jobs; see [23]) has problems: it is a form of futurism which avoids system change It is just saving capitalism. The end result must be a system which fixes all the other problems too.

We need complete system change. We do need to deal with things other than climate change. We have an ecological emergency; but also a fascist emergency. We need to raise awareness of fascism. I have changed my mind on racism. I do think we need to do more on that. XR should become accomplices to other groups working in similar areas. XR could put all of its resources into true direct action. I have been watching films of campaigns, like people standing in front of machines cutting down trees. This would create actual change while pressuring the government in the same way.
But why ask the government? We cannot trust the government in the first place. They will say, 'oh hey, we're meeting your demands', but they're not. We should be way more community-based. We should help other movements. The only sort of action we should do is that true direct action. So, a homeless person could not afford shop prices for food or clothes. It would be better to get arrested fighting for the homeless person to only pay \pm 5 . That would be amazing. It would do some good in the meantime. If we did that everyday, this would force companies to change. Using online activism, we can be a global network linking with local groups. We can help other groups, like those working for/with marginalised groups. We can help those who already have their own tactics. This is a more anarchist strategy.

After I read about the criticisms of XR that I had heard, I started to read on Wikipedia for Kids about different political systems: anarchism, capitalism, socialism and communism. Now I am favouring anarchism, which believes that there should be no government. Instead, all decisions are made locally, with the goal of fulfilling not just everyone's needs, but everyone's desires. Let us imagine how amazing the future could be under an anarchist programme. This will not happen naturally, but we have to try. The government will try to stop anarchism from happening. We need a group of anarchist-minded people rising up - lots of them - then we can end up with a big change. We are trying to change so many systems. Each one will take a while to get. So, why do we not change the system just one time, and fix all the problems in doing so? That means XR must work towards a system change which will help solve all the issues, but we are not, really, as we do not say anything about any of them in our demands. We do not need to wait: we can do it all now. It is still something we must do. But no, it is not necessary to do that in XR.

\section{Discussion}

What tentative inferences about learning can we draw from EL's account of her acts of rebellion? The word tentative here is apt, for three reasons: first, neither author of this article is an expert in educational theory; second, it is in analysing EL's words that the dangers of adultism and other power relations are most clear; and third, as the last section showed, EL's thoughts are changing, partly as her own circumstances change and partly as the nature of the external (political) environment alters. It is important to acknowledge that EL is a child who is developing and, necessarily, that she is influenced by immediate influences. She clearly is not the autonomous individual of liberal educational philosophy. She is, though, clearly a nimble thinker, able to re-cast her view of the world unencumbered by her previous ideas. 
Engeström [24] claims that any theory of learning must answer four questions: who, why, what, and how? Thus, we shall seek to answer those questions in this case. The 'who?' question sounds trivial but actually is not. EL is an 11-year old, but one clearly with a nonstandard biography. First, she has dedicated time and effort to environmental activism. Second, whilst she has attended school, she is essentially home-schooled and raised under a tradition of unschooling. Third, she has already lived in the UK, Colombia and Germany. Fourth, she has lived mainly in small towns or villages, mainly surrounded by adults. Collectively, these facts mean that her context is rather different from, say, a child in a large family, attending school, located in the same place. Her background is manifest in the learning opportunities she has had and her mode of learning; and hence the answers to Engeström's other three questions.

Why has EL learned? Here the influence of her context is clear. She has been free to learn, to be curious and playful, and to pursue her interests. In addition to her climate activism she has, for example, written (and selfpublished) fiction and learned how to play chess. For advocates of unschooling, she represents an exemplar. Of course, this method was contingent on her care arrangements, which were tailored to her not being in school; and to the social and intellectual capital of her parents and their wider social group. These social networks have, clearly, also affected her chosen interests. She describes growing up in a sustainability-aware environment, in which discussion of these issues was everpresent. It is perhaps unsurprising that EL took an ecoactivist turn, whereas the activism of Greta Thunberg may have emerged de novo. Both of these young people, however, were motivated by a profound sense of the current situation being wrong.

This ethical stance seems also to have emotional content: it is telling that EL uses the words 'scared' and 'sad'. Overall, we can say that EL has been motivated to learn in various ways or entry points [25], from idle curiosity to growing up in an environment in which sustainability is valued. It is clear, particularly in the most recent development of her thoughts, that the influence of her activist mother on her is significant.

What has EL learned? Again, this appears trivial. She has learned about climate change: she grasps key facts about it and the physical mechanisms underlying it. She has, though, learned more than this. She is developing a comprehension of how climate change relates with economy and society. She is constructing an understanding of the nature of the world, viewing climate change and its avoidance as systemic. In some respects, she is accumulating knowledge, but in other senses she is transforming her interpretation. One feature of this transformation is her grasping more abstract concepts and their interconnections. For example, she cites moving from ecological emergency to fascist emergency and cites racism, sexism and classism. In so doing, she reexamines her view on the role of national governments: earlier in our conversation she, as did XR, viewed them as crucial. Her more recent thinking, influenced by reading, has an anarchist flavour, favouring bottom-up action. She has also developed a sense of activism, of what motivates people, and therefore of strategy and tactics. She has also developed a moral framework for interpreting the world: she has a clear sense that climate change and things that perpetuate it are wrong, and that current (particularly adult) humans have duties to act to prevent catastrophic climate change being imposed on younger and future generations of humans and non-humans.

Engeström's fourth question is the most difficult, as how people learn is the site of considerable debate. What does seem clear is that EL has not learned in one way and does not conform to any single mode of learning. Let us briefly consider two connected strands within the literature: experiential learning (associated with [7, 26]; see also [27]) and social learning (associated with among others [28]).

Experiential learning has many variants, although all share the basic point that learning in some sense springs from experience. For Kolb [26] learning occurs in a continuous cycle in which experience triggers reflection, conceptualisation and experimentation. We can see these elements in EL's development. She has reflected on concrete experiences (social gatherings), reflected on these and constructed abstract conceptualisations, such as those of the current socio-economic system. Her recent change of mind shows evidence that she can reflect critically, even when she has to confront apparently cherished beliefs. Her recent questioning of XR's tactics is a reconceptualization of her understanding of system change. As Jarvis [29] notes, learning comes from experience partly because new experiences create disjuncture in the person. Children have more new experiences by virtue of having fewer old ones to draw on and therefore fewer reference points - experience is thus inherently more formative. In the language of Piaget [30], experiences and the new information therein can create a disequilibrium, which the child seeks to accommodate. One means of accommodation to let go of old mental models: children can do this more easily than adults.

Kolb's work cites that of Dewey; however, Elkjaer [8] among others argues that Dewey's work offers a richer picture than Kolb's in several respects. For Dewey, experience is "not primarily something associated with knowledge but with human beings' lives and living" ( $\mathrm{p}$. 74). Experience is transactional in the sense of a subject engaging with the world. It is thus not merely epistemological but ontological. Experience involves a felt 
encounter with a difficulty, leading to playful, experimental, future-oriented inquiry, hopefully leading to a resolution. As it is a felt encounter, it may be driven mainly by emotion or ethical concerns, and the desire to change the world, rather than a quest for knowledge. Future experience (defined thus) can be corrective, meaning that all knowledge is fallible, transient.

We can see these elements in EL's story. She felt sad and scared about climate change and inspired by the words and actions of those around her. That led her to actively seek knowledge, and inspired her into action, through which she engaged with the world, focused on the consequences of her actions on that world. As such, her experience is of the "subject as being in the world, not outside and looking into the world" ([8] p. 79) She has also demonstrated a quasiexperimental approach of trial-and-error: when she began each action, she did not know its likely outcome. For various complex reasons, she has now revised her understanding of the world and about what are good actions, that is, those likely to lead to desirable consequences.

As Jarvis [29] among others notes, despite learning occurring within the individual, individualist theories are flawed, because they assume an unwarranted mind/body dualism (p. 25). All psychological theories require a sociological dimension [31]. It might seem that experiential learning avoids some of these criticisms; but Jarvis claims it applies there as well. It is clear that experience generates meanings only through social mediation: thus, experience must recognise social context, but does not interrogate it. In this way, all learning occurs in social context and to some extent via social interaction. The autonomous individual of liberal educational philosophy is a myth.

As already noted, EL was home-schooled, mostly in small towns, without access to typical social networks that children have. She has also displayed an ability to direct her own activity (and hence learning). In some ways she exemplifies individualist theories of learning. Nonetheless, she has clearly been influenced by interactions in social groups, both in her formative years at home and in her activism. In EL's case, she has been affected significantly by her relationships with her parents. The influence of her mother in particular in exposing EL to ecological activism is clearly crucial. Here we see evidence of Vygotsky's [32] concept of learning from the more knowledgeable other as expanding EL's zone of proximal development: i.e. expanding what it is possible for her to learn by herself. It is clear that she in some senses has followed her mother in what she explores and what she ultimately believes; however, it is also clear that she is developing a personal understanding of the objects that she engages with. She is gradually taking ownership of her own learning.

Social learning theory, however, goes further than mere cognitive change from social interaction, arguing that learning inherently occurs in all aspects of life, all the time: it is not confined to set-piece learning events [33]. For Wenger [34] these processes of learning occur within communities of practice. We can see these factors very clearly in EL's case: she has learned via various routes and media. In doing so, she has developed her own mental structures; but she has also sought meaning and belonging, which for Wenger are key facets of learning. She has done so in various communities of practice, principally one around her home life, the other within activist groups.

\section{Conclusions}

This article reflects on the environmental activism of Elsie Luna, a (now) 11-year-old. It is the result of conversations between her and her co-author. The article raises interesting ethical and methodological issues about children as peer researchers, particularly about adultism and its limits. Indeed, the article suggests other reasons why adultism is wrong. One driver shared by EL, by Greta Thunberg and those inspired by her, is frustration that older generations are not acting. In terms of learning theory, there is a mismatch between the youth activists, agile in their thinking, and older generations, who struggle to let go of established ideas. In this respect, adultism appears wrong because the adults appear wrong.

The article draws upon theories of experiential and social learning to build a tentative understanding of what, why and how Elsie Luna has been learning about the environment, system change and political and moral decisions. It applies these theories to key events in EL's life, specifically those associated with Extinction Rebellion, a group with whom she was heavily involved and supportive of. Tentatively, we observe that EL is formulating views on sustainability, on system change and associated strategies, and developing a moral position on these matters. She has learned socially, from family and other immediate influences, and from activism. Thus, further, she has learned from experience, but in her own selfmanaged way.

It is significant that her views on these issues - including on XR, an organisation to whom she was fully committed - have changed in a short time, reflecting partly the fluidity of the material situation. More importantly, her changing views demonstrate her own development. We see her first formulate a set of views consistent with the manifesto of XR. We then see a shift in her thinking as she is exposed to new ideas about XR and about key social mechanisms, captured in abstract concepts and their interconnections. As a child, it is easier for EL to discard old ideas and re-think the world than it is for an adult such as AM. Some might dismiss her shift that as being mere incoherence; but pedagogically, EL is responding to a disjuncture by exploring, learning and developing a new world view, inspiring new transformative action. Elsie Luna was learning to rebel. 


\section{Acknowledgements}

the article has benefitted from comments by Eleanor Burke (referee), David Crookall (lead guest ed), Heather Luna, Guy McPherson (referee), Warren Thorngate (guest ed), Charlotte Weber (guest ed) and Howard Yeomans.

\section{Authors' contributions}

EL contributed the material in the italicised sections; AM prepared the manuscript; both authors read the manuscript. The author(s) read and approved the final manuscript.

\section{Funding}

none.

\section{Availability of data and materials \\ not applicable.}

\section{Ethics approval and consent to participate}

as one of the co-authors is a child, the adult co-author has checked for the child's assent throughout and also checked with her parents. See Methods section.

\section{Consent for publication}

this has been given throughout by Elsie Luna's parents. If further proof of this is needed, it can be provided.

\section{Competing interests}

none.

Received: 7 March 2020 Accepted: 7 May 2020

Published online: 27 May 2020

\section{References}

1. Foster J, editor. Facing up to climate reality: honesty, disaster and hope. London: London Publishing Partnership; 2019.

2. Vox: Photos: kids in 123 countries went on strike to protect the climate. https://www.vox.com/energy-and-environment/2019/3/15/18267156/youthclimate-strike-march-15-photos. (2019) Accessed 30 Apr 2019 at 15:21.

3. Webster B. The Times: Meet the British Greta Thunbergs who shoot from the lip https://www.thetimes.co.uk/article/meet-the-british-gretas-who-shootfrom-the-lip-3656vdj7j Accessed 06 Apr 2020 at 10:23.

4. Tincon: Warum nicht den Planeten schützen, wenn es sonst niemand tut?" - Interview mit Elsie Luna. https://tincon.org/2019/01/07/warum-nicht-denplaneten-schuetzen-wenn-es-sonst-niemand-tut-interview-mit-elsie-luna/ (2018) Accessed 30 Aug 2019 at 15:22

5. Flasher J. Adultism. Adolescence. 1978;13(51):517-23.

6. Dewey J. The reflex arc concept in psychology. Psych Rev. 1896:3(4):357-70.

7. Dewey J. Democracy and education (1916). Middle Works Bd, 9; 1966

8. Elkjaer B. Pragmatism: learning as creative imagination. In: Illeris K, editor. Contemporary theories of learning. London: Routledge; 2009. p. 74-89.

9. Coppock V. Children as peer researchers: reflections on a journey of mutual discovery. Child Soc. 2011;25(6):435-46.

10. Kellett, M., 2005. Children as active researchers: a new research paradigm for the 21st century?. Available at http://oro.open.ac.uk/7539/ [accessed 23 Dec 19, 11:51].

11. Tate TF, Copas RL. Insist or enlist?: Adultism versus climates of excellence. Reclaiming Children and Youth. J Strength-Based Interventions. 2003;12(1): 40-5.

12. Gallacher LA, Gallagher M. Methodological immaturity in childhood research? Thinking through participatory methods. Childhood. 2008;15(4): 499-516.

13. Extinction Rebellion: Principles and Values. https://rebellion.earth/the-truth/ about-us/ (2019) Accessed 30 Aug 2019 at 15:20.

14. Mollison B. Permaculture: A designer's manual: Tagari publications; 1988

15. Dalton J. The Independent: Extinction Rebellion activists who glued themselves to trains spared jail as judge notes 'noble' cause https://www. independent.co.uk/news/uk/home-news/extinction-rebellion- climate-traincanary-wharf-glue-jail-court-a9254321.html Accessed 06 Apr 20, 14:32.

16. Dodd S. Sandra Dodd's big book of unschooling. Com: Lulu; 2009.

17. Gray P, Riley $G$. The challenges and benefits of unschooling, according to 232 families who have chosen that route. J of Unschooling \& Alternative Learning, vol. 7; 2013. p. 14
18. BBC News: Extinction Rebellion postpone Heathrow drone protest https:// www.bbc.co.uk/news/uk-england-Iondon-48652840. Accessed 06 Apr 20, 14 37.

19. Gayle D. The Guardian: Does Extinction Rebellion have a race problem? https://www.theguardian.com/environment/2019/oct/04/extinctionrebellion-race-climate-crisis-inequality (2019). Accessed 23 Dec 19, 11:50.

20. Ahmed $\mathrm{N}$. The flawed science behind extinction rebellion's change strategy https://medium.com/insurge-intelligence/the-flawed-science-behindextinction-rebellions-change-strategy-af077b9abb4d (2019). Accessed 23 Dec 19, 17:15.

21. Smoke B. The Guardian: Extinction Rebellion protesters who want to be arrested: Be careful what you wish for. https://www.theguardian.com/ commentisfree/2019/apr/15/extinction-rebellion-protesters-arrestedstansted-15. (2019). Accessed 23 Dec 19 11:33.

22. Connolly K. and Taylor M. The Guardian: Extinction Rebellion founder's holocaust remarks spark fury. https://www.theguardian.com/environment/2 019/nov/20/extinction-rebellion-founders-holocaust-remarks-spark-fury (2019). Accessed 23 Dec 19, 17:15.

23. New Economics Foundation: Green New Deal. https://neweconomics.org/ campaigns/green-new-deal (2019). Accessed 23 Dec 19, 11:49.

24. Engeström $Y$. Expansive learning: towards an activity-theoretical reconceptualization. In: Illeris K, editor. Contemporary theories of learning. London: Routledge; 2009. p. 53-73.

25. Gardner H. Howard Gardner on making the most of young minds. Education Digest. 2000;65(6):4.

26. Kolb DA. Experiential learning: experience as the source of learning and development. London: FT press; 2014

27. Jarvis P. Adult learning in the social context. London: Croom Helm; 1987.

28. Lave J, Wenger E. Situated learning: legitimate peripheral participation. Cambridge: Cambridge university press; 1991

29. Jarvis P. Learning to be a person in society: learning to be me. In: Illeris K, editor. Contemporary theories of learning. London: Routledge; 2009. p. 21-

30. Piaget J. Origins of intelligence in the child. London: Routledge \& Kegan Paul; 1936.

31. Wenger E. A social theory of learning. In: Illeris K, editor. Contemporary theories of learning. London: Routledge; 2009. p. 209-18.

32. Vygotsky L. Mind in society: the development of higher psychological processes. Cambridge MA: Harvard university press; 1980.

33. Lave J. The practice of learning. In: Illeris K, editor. Contemporary theories of learning. London: Routledge; 2009. p. 200-8.

34. Wenger E. Communities of practice: learning, meaning and identity. Cambridge, MA: Harvard University Press; 1998.

\section{Publisher's Note}

Springer Nature remains neutral with regard to jurisdictional claims in published maps and institutional affiliations.

Ready to submit your research? Choose BMC and benefit from:

- fast, convenient online submission

- thorough peer review by experienced researchers in your field

- rapid publication on acceptance

- support for research data, including large and complex data types

- gold Open Access which fosters wider collaboration and increased citations

- maximum visibility for your research: over $100 \mathrm{M}$ website views per year

At $\mathrm{BMC}$, research is always in progress.

Learn more biomedcentral.com/submission 